\title{
Civil Rights Attorney's Fees Awards in Moot Cases
}

\section{The Civil Rights Attorney's Fees Awards Act of $1976^{1}$ (the}

"Act") authorizes an award of attorney's fees to the "prevailing party" in certain civil rights actions. "The precise meaning of "prevailing party," left undefined by the Act, is the subject of much debate. ${ }^{3}$ A plaintiff ${ }^{4}$ who has gained his desired relief through final

${ }^{1}$ Pub. L. No. $94-559,90$ Stat. 2641 (1976) (codified as amended at 42 U.S.C.A. $\S 1988$ (West 1981)).

2 In any action or proceeding to enforce a provision of sections 1981, 1982, 1983, 1985, and 1986 of this title, title IX of Public Law 92-318 [20 U.S.C. 1681 et seq.], . . or title VI of the Civil Rights Act of 1964 [42 U.S.C. 2000d et seq.], the court, in its discretion, may allow the prevailing party, other than the United States, a reasonable attorney's fee as part of the costs.

42 U.S.C.A. $\$ 1988$ (West 1981) (brackets in original).

The Act also authorized fees awards in certain suits brought under the Internal Revenue Code. Civil Rights Attorney's Fees Awards Act of 1976, Pub. L. No. 94-559, § 2, 90 Stat. 2641, 2641 (currrent version at 42 U.S.C.A. $\$ 1988$ (West 1981)). That provision was repealed by the Equal Access to Justice Act, Pub. L. No. 96-481, § 205(c), 94 Stat. 2321, 2330 (1980). Few fees awards were made under section 1988 in tax cases, but the wider applicability of the new Act will allow more such awards. See generally Janes, The Equal Access to Justice Act: When Will it Permit Recovery of Attorneys' Fees?, 56 J. TAx'N 164 (1982). Specifically, the new act authorizes fees awards "to a prevailing party other than the United States . . . in any civil action . . . brought by or against the United States . . . unless the court finds that the position of the United States was substantially justified or that special circumstances make an award unjust." 28 U.S.C.A. § 2412(d)(1)(A) (West Supp. 1982). Cf. 5 U.S.C.A. $\$ 504(a)(1)$ (West Supp. 1982) (using similar language to authorize fees awards in certain administrative proceedings).

- See Lipson, Beyond Alyeska-Judicial Response to the Civil Rights Attorneys' Fees Act, 22 ST. LouIs U.L.J. 243, 253-61 (1978); Note, Interim Awards of Attorneys' Fees Under the Civil Rights Attorney's Fees Awards Act of 1976, 21 ARIz. L. REv. 893, 908-12 (1979) [hereinafter cited as Arizona Note]; Note, Promoting the Vindication of Civil Rights Through the Attorney's Fees Awards Act, 80 Colum. L. Rev. 346, 353-55 (1980) [hereinafter cited as Columbia Note]; Comment, Attorney's Fees in Damage Actions Under the Civil Rights Attorney's Fees Awards Act of 1976, 47 U. CHr. L. Rev. 332, 350 n.95 (1980).

- The party asserting a civil rights claim and seeking a fees award will not always be the plaintiff; for example, it could be an intervenor or a defendant asserting a counterclaim or cross-claim. See S. Rep. No. 1011, 94th Cong., 2d Sess. 4 n.4 (1976) [hereinafter cited as Senate Report], reprinted in 1976 U.S. Code Cong. \& Ad. News 5908, 5912 n.4. Cf., e.g., Commissioners Court v. United States, 683 F.2d 435, $439-40$ (D.C. Cir. 1982) (defendantintervenors treated as plaintiffs for purposes of fees award under 42 U.S.C. $\$ 1973 l(\mathrm{e})$ (1976) because they were seeking to vindicate constitutional rights). For simplicity, however, this comment will refer to the civil rights claimant as the "plaintiff" or the "fee claimant," and to his opponent as the "defendant." Fees are generally unavailable to the defendant. See infra note 24. 
judgment on the merits of a civil rights claim is undeniably a prevailing party; the judgment establishes that desired relief was obtained, that it was obtained through the lawsuit, and that the relief was for a civil rights violation. Dismissal of a plaintiff's suit for mootness, ${ }^{5}$ in contrast, fails to prove any of these elements. Because a dismissal for mootness may result from any one of a number of circumstances, and because such dismissals preclude final adjudication of the merits, determining whether the plaintiff has "prevailed" is a difficult task not subject to any automatic test. In the absence of guidance from the Supreme Court, the lower federal courts are divided on the proper standards to apply. ${ }^{\circ}$

This comment explores whether a party can "prevail," for purposes of the Act, when dismissal for mootness prevents final adjudication of the merits of his claim. The comment first reviews Congress's understanding of the term "prevailing party" and its purposes in passing the Act to show that rules either automatically awarding or automatically denying fees in moot cases are inconsistent with Congress's intent. The comment then tests several limiting principles and concludes that attorney's fees should be awarded where the plaintiff achieved some of the relief he desired, the relief resulted at least in part from the lawsuit, and the complaint stated a legally cognizable civil rights claim. The final part of the comment explores the application of these principles.

\section{Congressional Purposes and Per Se Rules}

\section{A. Fees Awards}

Congress intended that the civil rights laws be enforced primarily through private litigation. ${ }^{7}$ Private civil rights enforcement

- A case is moot when it no longer presents a justiciable controversy because the disputed issue has been resolved, has ceased to exist, or is otherwise academic. Federal courts may not hear cases that are not amenable to concrete resolution through conclusive, rather than advisory, opinions. U.S. ConsT. art. III, § 2, para. 1 (extending "judicial Power" to "Cases" and "Controversies"). "[M]oot cases are held to be beyond the judicial power [because t] here is no case or controversy once the matter has been resolved." C. WrighT, HandBook of the LAW of Federal Courts $\S 12$, at 39 (3d ed. 1976). On the contours of mootness doctrine, see generally Sosna v. Iowa, 419 U.S. 393, 398-403 (1975); DeFunis v. Odegaard, 416 U.S. 312, 316-20 (1974); Moore v. Ogilvie, 394 U.S. 814, 816 (1969); Golden v. Zwickler, 394 U.S. 103, 108-10 (1969); United States v. W.T. Grant Co., 345 U.S. 629, 632-33 (1953); D. Currie, Federal Courts: Cases and Materials 104-07 (2d ed. 1975).

- See infra notes 25-33 and accompanying text.

7 H.R. REP. No. 1558, 94th Cong., 2d Sess. 1-2 (1976) [hereinafter cited as House REPORT]; Senate Report, supra note 4, at 2-4, reprinted in 1976 U.S. Code Cong. \& Ad. News at 5910-11. See also infra note 48. In a remark typical of those made by the sponsors of the 1976 Act, Senator Kennedy stated that "[p]rivate enforcement of these laws by those most 
benefits the public as well as the individual whose rights have been violated. The public may benefit directly, as, for example, from suits that protect the right to vote ${ }^{8}$ or to travel. ${ }^{8}$ In addition, all civil rights enforcement benefits the public indirectly to the extent that it penalizes violators and thus deters others from similar violations. $^{10}$

Despite the premium most people place on their civil rights, there are two serious disincentives to bringing private suits to enforce those rights. First, because civil rights remedies often are only equitable, ${ }^{11}$ a plaintiff must finance the litigation without hope of recovering a damage award out of which to pay a lawyer. Few people can afford this cost. ${ }^{12}$ Second, even when the public would benefit greatly from a suit, there is little incentive for any one individual to undertake the lawsuit because he would be paying for benefits he could receive free if someone else brought the suit. $^{13}$

To overcome these disincentives, Congress included attorney's fees awards provisions in many of the modern civil rights statutes, ${ }^{14}$ and fees are commonly awarded in suits brought under those statutes. ${ }^{15}$ The possibility of recovering fees promotes private civil rights litigation and enforcement in four ways. First, the prospect of payment attracts lawyers to impecunious plaintiffs. Second, it encourages speedy resolution of rights violations. If a defendant has a losing case, dragging out the litigation through legal gamesmanship will only increase the cost he will have to bear in the end. Third, fees awards deter rights violations by adding to the liability of violators who are caught. ${ }^{16}$ Finally, by increasing the number of

directly affected must continue to receive full congressional support. Fee shifting provides a mechanism" for providing such support. 122 Cong. REc. 31,472 (1976). See Columbia Note, supra note 3, at 350; Comment, supra note 3, at 344 .

- E.g., Baker v. Carr, 369 U.S. 186 (1962).

- E.g., Shapiro v. Thompson, 394 U.S. 618 (1969).

10 See Carey v. Piphus, 435 U.S. 247, 256-57 (1978).

11 See House REPORT, supra note 7, at 9. Only about one-fourth of the civil rights cases cited in this comment involve damages claims.

12 House Report, supra note 7, at 1-2, 9; SenAte Report, supra note 4, at 2-4, reprinted in 1976 U.S. Code ConG. \& AD. News at 5910-11.

${ }^{13}$ This is the classic free-rider problem often described in law-and-economics literature. See R. Posner, Economic Anazysis of Law 351, 468-69 (2d ed. 1977).

16 E.g., Voting Rights Act Amendments of 1975 , $\$ 402,42$ U.S.C. $\$ 1973 l(\mathrm{e})$ (1976); Civil Rights Act of 1964, § 204(b), 42 U.S.C. $\$ 2000 \mathrm{a}-3(\mathrm{~b})(1976) ; i d . \S 706(\mathrm{k}), 42$ U.S.C. $\S 2000 \mathrm{e}-$ 5(k) (1976); Fair Housing Act of 1968, § 812(c), 42 U.S.C. \& 3612(c) (1976).

${ }^{15}$ E.g., Newman v. Piggie Park Enters., 390 U.S. 400 (1968) (per curiam); Johnson v. Georgia Highway Express, Inc., 488 F.2d 714 (5th Cir. 1974).

16 See Comment, supra note 3, at 344-48. See also Carey v. Piphus, 435 U.S. 247, 257 
enforcement suits, fees awards raise the probability that any given violator will be found liable and be penalized.

Although the Reconstruction-era civil rights laws ${ }^{17}$ do not provide for fees awards, until 1975 courts often awarded fees in suits brought under those laws, ${ }^{18}$ relying on the "private attorney general" theory ${ }^{10}$ and reasoning that concerns of equity and consistency required a uniform fees policy wherever individuals advanced the public interest through civil rights litigation. In Alyeska Pipeline Service Co. $v$. Wilderness Society, ${ }^{20}$ however, the Supreme Court rejected the private attorney general theory as an invasion of "the legislature's province."21 The Court held that absent specific statutory authorization, each side ordinarily must bear its own legal costs. ${ }^{22}$

After Alyeska, therefore, fees awards under the Reconstruction-era laws were generally forbidden, but awards could still be made in cases brought under the modern civil rights laws. In order "to remedy [these] anomalous gaps in our civil rights laws" created by Alyeska and to encourage private civil rights suits in a consistent manner, ${ }^{28}$ Congress enacted the Fees Awards Act, amending section 1988 of Title 42 of the United States Code ("section 1988") to provide for the award of attorney's fees to a "prevailing party" in actions brought under the Reconstruction-era statutes. ${ }^{24}$

n.11 (1978).

1742 U.S.C. $\S \S 1981-1983,1985-1986$ (1976).

1s See Fowler v. Schwarzwalder, 498 F.2d 143'(8th Cir. 1974) (case brought under sections 1981 and 1983); Hoitt v. Vitek, 495 F.2d 219 (1st Cir. 1974) (section 1983); Cornist v. Richland Parish School Bd., 495 F.2d 189 (5th Cir. 1974) (section 1983); Cooper v. Allen, 467 F.2d 836 (5th Cir. 1972) (section 1981); Knight v. Auciello, 453 F.2d 852 (1st Cir. 1972) (section 1982); Sims v. Amos, 340 F. Supp. 691 (M.D. Ala.) (section 1983), aff'd mem., 409 U.S. 942 (1972).

10 The theory is that when a private litigant successfully enforces an important public policy, he has acted as a "private attorney general" and is entitled to reimbursement of litigation expenses even absent statutory authorization. E.g., Fowler v. Schwarzwalder, 498 F.2d 143, 145 (8th Cir. 1974) ("[A] plaintiff who acts as a 'private attorney general' in seeking to vindicate Congressional policy of the highest priority and advance the public interest should not be forced to bear the costs of litigation."); 6 J. Moore, Moore's Federal PracTICE I 54.77[2], at 89 (2d ed. 1948 \& Supp. 1981).

20421 .U.S. 240 (1975).

21 Id. at 271. See id. at 269-71.

22 The Court held that without such authorization, fees can be awarded only when a common fund exists; when the opponent's conduct is vexatious, harassing, or in bad faith; or when the opponent willfully violates a court order. Id. at 257-59.

${ }^{23}$ Sennte Report, supra note 4, at 1, reprinted in 1976 U.S. Code Cong. \& Ad. News at 5909 .

24 Civil Rights Attorney's Fees Awards Act of 1976, Pub. L. No. 94-559, 90 Stat. 2641 (codified as amended at 42 U.S.C.A. $\$ 1988$ (West 1981)). The language of section 1988 appears inconsistent with these policies because it makes awards a matter of discretion and 


\section{B. Moot Cases}

It might be argued that "prevailing" does not depend on whether a court has ordered relief. As a practical matter, a plaintiff has prevailed in a moot case if he has obtained some or all of the relief originally sought. Moreover, the relief is final and irrevocable because mootness precludes further adjudication. Therefore, courts could adopt a per se rule in favor of a fees award whenever the plaintiff can demonstrate that he has obtained relief. ${ }^{25}$

This argument has several flaws, however. First, that the outcome is irrevocable does not mean that it was mandated by law. It is unjust to force the defendant to pay attorney's fees when the plaintiff's relief was not, and could not properly have been, awarded after a trial on the merits. Second, the defendant may have accommodated the plaintiff for reasons unrelated to the lawsuit, ${ }^{28}$ or the relief may have resulted from the acts of someone other than the defendant. ${ }^{27}$ In either event, relief was not obtained by the plaintiff qua party to a lawsuit; although he may have prevailed, he is not necessarily a prevailing party. Third, the relief ob-

does not distinguish between prevailing plaintiffs and defendants. Both features could discourage potential civil rights plaintiffs: not only might the trial court refuse to award fees should they win, but it could force them to pay the defendant's fees should they lose. Precisely because such a reading would confound the Act's purposes, however, Congress made it clear that it did not mean for the words to be applied literally. The House and Senate Reports indicate that because the Act copied the language of the fees provisions of the Civil Rights Act of 1964, $\S \S 204(\mathrm{~b}), 706(\mathrm{k}), 42$ U.S.C. $\S \S 2000 \mathrm{a}-3(\mathrm{~b}), 2000 \mathrm{e}-5(\mathrm{k})$ (1976), the case law under the earlier statute was to be applied. HouSE REPORT, supra note 7, at 5-6; SENATE REPorT, supra note 4, at 4, reprinted in 1976 U.S. CODE ConG. \& AD. NEws at 5912. Those cases mandate that a successful plaintiff recover his fees as a matter of course, House REPORT, supra note 7, at 5-6; SBNATE REPORT, supra note 4, at 4, reprinted in 1976 U.S. CoDE CoNG. \& AD. NBws at 5912, but that a prevailing defendant receive fees only in exceptional cases, as where the plaintiff's suit is "clearly frivolous, vexatious, or brought for harassment purposes," SEnate RePort, supra note 4, at 5, reprinted in 1976 U.S. Code Cong. \& AD. News at 5912.

${ }^{28}$ For example, in Bagby v. Beal, 606 F.2d 411 (3d Cir. 1979), the trial court granted the plaintiff injunctive relief, and the order was carried out before the case was heard on appeal. The Third Circuit found the case moot, but affirmed the trial court's award of nearly $\$ 9000$ in attorney's fees because the plaintiff had prevailed in substance by receiving the benefits of the injunctive relief. The court explained that "[t]his holding is not dependent on the correctness of the district court's decision on the merits. No future proceedings involving the merits of the controversy will change this result . . . "Id. at 415 .

26 E.g., Marci v. City of New Haven, 503 F. Supp. 6 (D. Conn. 1980) (plaintiff dismissed from city employment; case mooted when plaintiff's political ally was elected mayor and reinstated plaintiff to better position); Flesch v. Eastern Pa. Psychiatric Inst., 472 F. Supp. 798 (E.D. Pa. 1979) (plaintiff challenged dismissal through both lawsuit and grievance procedure; lawsuit mooted when arbitrator ordered her reinstated).

${ }_{27}$ E.g., Criterion Club v. Board of Comm'rs, 594 F.2d 118 (5th Cir. 1979) (plaintiffs challenged at-large election of county commissioners by suing the Board of Commissioners; case mooted by election amendment enacted by state legislature). 
tained may not have corrected a civil rights violation. ${ }^{28}$ Finally, a rule awarding fees to any plaintiff who obtains some relief could be manipulated by plaintiffs and could encourage unnecessary litigation. Prevailing defendants generally cannot recover their fees.90 Therefore, a potential plaintiff without a legitimate civil rights claim might initiate litigation in the hope that the defendant will choose to accommodate him and pay his attorney's fees, rather than undertake extended litigation and have to pay his own lawyer.

Perhaps because of these problems, a few courts have adopted the opposite per se rule that "a plaintiff cannot be a prevailing party where his claim is dismissed as moot." Mootness precludes adjudication of the merits, and without adjudication neither party can be said to have prevailed formally. Justice Rehnquist has argued that awarding fees without adjudicating the merits penalizes the paying party without allowing him to prove that he was in the right. $^{31}$ Under standard mootness doctrine, when a case becomes moot before a decision on final appeal, any decision made prior to that point is vacated or reversed so that neither party is further prejudiced by the case. ${ }^{32}$ In Justice Rehnquist's view, an award of fees in the face of mootness constitutes additional prejudice, leaves the paying party harmed rather than whole, is not obviously authorized by the statute, and is condemned by precedent. ${ }^{33}$

A per se rule against fees awards in moot cases is nonetheless unjustified. First, reliance on mootness doctrine is misplaced. Mootness precludes further action on the underlying civil rights claim that would prejudice either party, but the attorney's fees claim is distinct, with a separate statutory basis. The court still must determine whether either party has prevailed, not to adjudicate the civil rights claim, but for purposes of section 1988.94

${ }^{28}$ E.g., Cicero v. Olgiati, 473 F. Supp. 653 (S.D.N.Y. 1979) (fees denied where court skeptical about validity of plaintiffs' civil rights claim). But see infra notes $106-09$ and accompanying text.

28 See supra note 24.

${ }^{30}$ Cramer v. Virginia Commonwealth Univ., 486 F. Supp. 187, 192 n.7 (E.D. Va. 1980). Accord, Ward v. Arkansas State Police, 493 F. Supp. 1315, 1328 (E.D. Ark. 1980), rev'd on other grounds, 653 F.2d 346 (8th Cir. 1981).

31 Alioto v. Williams, 450 U.S. 1012, 1013-14 (1981) (Rehnquist, J., dissenting from denial of certiorari). Accord, Marshall v. Doe, 451 U.S. 993, 993 (1981) (Rehnquist, J., dissenting from denial of certiorari).

${ }^{32}$ Alioto v. Williams, 450 U.S. 1012, 1013-14 (1981) (Rehnquist, J., dissenting from denial of certiorari). See also United States v. Munsingwear, Inc., 340 U.S. 36, 39-40 (1950).

ss Alioto v. Williams, 450 U.S. 1012, 1014 (1981) (Rehnquist, J., dissenting from denial of certiorari). Justice Rehnquist may be relaxing his position somewhat. See infra note 69.

34 E.g., Williams v. Alioto, 625 F.2d 845, 848 (9th Cir. 1980) ("Claims for attorneys' fees 
Second, the notion that "prevailing" requires formal adjudication of the civil rights claim is inconsistent with the legislative history of the Act. Although Congress did not mention moot cases, it explicitly authorized fees awards in many other situations falling short of a full trial on the merits..$^{35}$ Both the House and Senate Reports state that in some circumstances fees may be awarded pendente lite, such as in school desegregation cases where it often takes years to fashion remedies and final orders after a violation has been found.$^{36}$ Fees may also be awarded when the suit ends in an out-of-court settlement ${ }^{37}$ or a consent decree. ${ }^{38}$ Moreover, the Senate Report cites a number of cases supposed to be illustrative of those where "parties may be considered to have prevailed ... without formally obtaining relief." notes that fees may be awarded to a plaintiff who gains relief for a pendent state law or non-civil-rights claim but receives no decision on his civil rights claim..$^{40}$

ancillary to the case survive independently . . . and may be heard even though the underlying case has become moot."), cert. denied, 450 U.S. 1012 (1981); Bagby v. Beal, 606 F.2d 411, 414 (3d Cir. 1979) (argument that plaintiff had not prevailed "does not require us to look at the merits of this case and does not disturb our conclusion that this case is moot").

as It might be argued that Congress's failure to mention specifically awards in moot cases indicates, by negative inference, that it did not authorize such awards. Conversely, Congress may have ratified such awards by authorizing awards in cases where a party prevails "without formally obtaining relief." See infra note 39 and accompanying text. It is most likely that Congress did not consider mootness at all. The issue arises infrequently-only about 30 cases involving mootness and section 1988 have been reported in the six years since the Act was passed-and is not an obvious problem. In any event, mootness is indistinguishable from the listed categories. See infra notes 36-49 and accompanying text.

${ }^{36}$ House REPORT, supra note 7, at 8; SENATE REPORT, supra note 4, at 5, reprinted in 1976 U.S. Code Cong. \& AD. News at 5912.

${ }^{37}$ House REPORT, supra note 7, at 7.

28 Id.; Senate REPoRT, supra note 4, at 5, reprinted in 1976 U.S. Code Cong. \& AD. News at 5912 .

30 Senate Report, supra note 4, at 5, reprinted in 1976 U.S. Code Cong. \& AD. News at 5912. At least four of the five cases cited in the report can be explained as "catalyst" cases: the litigation caused another party to take some action beneficial to the party receiving fees. Thus in Kopet v. Esquire Realty Co., 523 F.2d 1005 (2d Cir. 1975), the defendants produced documents that they had been duty-bound to prepare long before. In Parham v. Southwestern Bell Tel. Co., 433 F.2d 421 (8th Cir. 1970), the lawsuit "acted as a catalyst which prompted" the defendant to comply with Title VII. Id. at 429-30. In Thomas v. Honeybrook Mines, Inc., 428 F.2d 981 (3d Cir. 1970), cert. denied, 401 U.S. 911 (1971), the intervenors' actions forced the plaintiffs to commence delinquency suits on behalf of the plaintiffs and the intervenors. Finally, in Aspira of New York, Inc. v. Board of Educ., 65 F.R.D. 541 (S.D.N.Y. 1975), the lawsuit resulted in a consent decree. The fifth suit, Richards v. Griffith Rubber Mills, 300 F. Supp. 338 (D. Or. 1969), seems to be an example of voluntary compliance not prompted by the suit.

40 The House Report states that fees may be awarded without a decision on the civil rights claim so long as it is substantial, and both it and the non-civil-rights claim on which the party won derive from a "common nucleus of operative fact." " House REPORT, supra 
Although Congress clearly did not make formal adjudication a prerequisite for a fees award, one might still distinguish mootness from these other situations in which Congress authorized fees awards. In the cases of settlement ${ }^{41}$ and consent decree, ${ }^{42}$ one can infer that the fee-paying party has waived adjudication. In the case of awards pendente lite ${ }^{4}$ there is a chance for redress on appeal, and fees can be awarded contingent upon posting bond. ${ }^{44}$ In contrast, the fee payer in a moot case has no choice in the matter of adjudication. Litigation on the merits is precluded by operation of law, not waived voluntarily. ${ }^{45}$ And whatever the merits, the feepaying party has lost by having to pay fees, with no redress on appeal possible..48

The element common to all of the situations for which Congress endorsed fees awards without final adjudication is not, however, that adjudication has been waived. It is that the plaintiff obtained final relief without a judgment. This element is shared by the moot case situation. ${ }^{47}$ Moreover, Congress's willingness to

note 7, at 4 n.7 (quoting UMW v. Gibbs, 383 U.S. 715, 725 (1966)). Because civil rights claims are likely to involve constitutional issues, courts will often refuse to rule on them when other grounds are dispositive. Id. See, e.g., Kimbrough v. Arkansas Activities Assoc., 574 F.2d 423 (8th Cir. 1978) (decision on constitutional issue unnecessary where injunction granted based on court's interpretation of challenged rule; fees awarded); Seals v. Quarterly County Court, 562 F.2d 390 (6th Cir. 1977) (awarding attorney's fees to plaintiffs whose voting district apportionment suit, brought as a section 1983 action, was decided on pendent state claim only). See also Maher v. Gagne, 448 U.S. 122, 132 (1980) (unanimous agreement that fees may be awarded "in a case in which the plaintiff prevails on a wholly statutory, non-civil-rights claim pendent to a substantial constitutional claim"); Comment, Civil Rights Attorneys' Fees in Cases Resolved on State Pendent and Federal Statutory Grounds, 130 U. PA. L. Rev. 488 (1981).

11 See supra note 37.

12 See supra note 38.

4 See supra note 36.

4 See Arizona Note, supra note 3, at 912.

${ }^{45}$ In this sense, fees awards in moot cases resemble awards based on pendent state law victories, which Congress authorized. There, too, the civil rights claim is never adjudicated because of the operation of law rather than any waiver by the fee-paying party. See supra note 40 and accompanying text.

45 Justice Rehnquist implied a "waiver" distinction in his Alioto dissent. The plaintiffs in that case had secured a preliminary injunction that was being appealed when the case became moot. Justice Rehnquist argued that treating the plaintiffs as prevailing parties on the basis of the preliminary injunction ignored

the fact that [the defendants] exercised their right to appeal the entry of that order and the fact that the propriety of the injunction was being challenged on appeal at the time the case became moot and the appeal dismissed. No permanent injunction ever issued and there has been no settlement or consent decree.

Alioto v. Williams, 450 U.S. 1012, 1013 (1981) (Rehnquist, J., dissenting from denial of certiorari).

${ }^{47}$ See supra note 25 and accompanying text. 
award fees when there has been no adjudication reflects its principal concern: to " 'encourage individuals injured . . . [ [by rights violations] to seek judicial relief." "48 Congress intended awards of attorney's fees to be part of the remedy for civil rights violations; in effect, fees awards complement the substantive relief gained." Thus, where a plaintiff gains relief for a civil rights violation, it would be anomalous to refuse fees simply because the case became moot before it was adjudicated.

Finally, there is a danger that a per se rule against fees in moot cases would be manipulated by defendants. For example, if the plaintiff obtained preliminary injunctive relief that imposed negligible costs on the defendant, ${ }^{50}$ the defendant could appeal the order and try to delay decision until the case became moot, thereby avoiding having to pay a fees award. Similarly, a defendant, particularly one with a losing case, might comply with the plaintiff's prayer for relief, thereby mooting the case and escaping payment of attorney's fees. ${ }^{51}$ In both situations civil rights violations may have been remedied because of litigation, but no fees would be awarded. This circumvention of the statute would discourage victims of civil rights violations from filing suit for fear of

4 Senate Report, supra note 4, at 3, reprinted in 1976 U.S. Cods Cong. \& AD. News at 5910 (quoting Newman v. Piggie Park Enters., 390 U.S. 400, 402 (1968) (affirming award of fees under the Civil Rights Act of 1964)).

There has never been any question that the Act was designed to encourage litigation. Its sponsor, Senator Tunney, said that the need for private enforcement of the civil rights laws "has been recognized in statutes specifically giving private citizens the right to go to court to redress grievances . . . . But without the availability of counsel fees, these rights exist only on paper." 122 Cong. Rzc. 33,313 (1976). Senator Kennedy said that the bill reflected a concern for "removing . . . barriers which have the effect of denying citizens full access to the courts in order to secure their legal rights." Id. at 31,472 . He also noted that "[w] vate rights or encourage more vigorous enforcement of Federal laws, Congress frequently includes fee-recovery provisions in its enactments." Id.

4s The Senate Report speaks of attorney's fees awards as "an integral part of the remedy necessary to achieve compliance with our statutory policies." SRNATE RBPORT, supra note 4, at 3, reprinted in 1976 U.S. Code CoNG. \& AD. NBws at 5910. Similarly, the House Report argues that fees awards are necessary to make "the judicial remedy . . . full and complete," not "meaningless." House RePoRT, supra note 7, at 1 .

${ }^{\text {so }}$ E.g., Doe v. Marshall, 622 F.2d 118 (5th Cir. 1980) (preliminary injunction allowing plaintiff to play high school sports became moot before appeal decided; fees awarded), cert. denied, 451 U.S. 993 (1981); Kimbrough v. Arkansas Activities Assoc., 574 F.2d 423 (8th Cir. 1978) (same).

s1 E.g., Robinson v. Kimbrough, 652 F.2d 458 (5th Cir. 1981) (suit to include more blacks and women on jury lists mooted after defendants recompiled lists and increased numbers of blacks and women); Striano v. New York State Office of Mental Health, No. 81 Civ. 4606 (HFW) (S.D.N.Y. Apr. 1, 1982) (challenge to state civil service law mooted when defendant offered to comply with procedures requested by plaintiff). 
having to pay attorney's fees should their cases become moot. Section 1988 was designed to encourage litigation by eliminating the cost barrier; a blanket rule against fees in moot cases directly contravenes this purpose.

\section{Three Criteria for Fees Awards}

Neither a per se rule granting fees in moot cases nor a per se rule denying fees in moot cases comports with congressional intent. This part develops a middle course defined by three conditions precedent for fees awards: the plaintiff must demonstrate that he actually obtained relief; the relief must in some way have been the result of the lawsuit; and the suit must have concerned a legally cognizable civil rights claim. ${ }^{22}$

In Hanrahan v. Hampton, ${ }^{\text {ss }}$ the Supreme Court stated that section 1988 awards are proper when a party "has established his entitlement to some relief on the merits of his claims, either in the trial court or on appeal." This suggests that the Court might require judicial recognition of entitlement to relief before fees may ever be awarded.5 This dictum should not be read so sweepingly, however, for Congress explicitly authorized fees awards in cases ending in settlements and consent decrees, where the merits are never adjudicated. ${ }^{\mathrm{s}}$ Nonetheless, Hanrahan establishes that the

${ }^{82}$ The simplest solution to the fees question, if per se rules are rejected, would be to leave the decision entirely to the discretion of the trial judge. Fees litigation would thus tend to be rudimentary and not involve prolonged efforts to fit the details of the case into a complicated set of rules. The trial court's decision could be reversed only if it was based on either of the extreme rules rejected here.

There are three problems with this approach. First, Congress intended to limit judicial discretion to avoid uncertainty about fees awards and thereby to minimize the resulting deterrence to litigation. Ad hoc decisions in moot cases would have the opposite effect. Second, the actual amount of the award is governed by highly articulated rules, see, e.g., Johnson v. Georgia Highway Express, Inc., 488 F.2d 714, 717-19 (5th Cir. 1974) (Title VII case); House REPORT, supra note 7, at 8-9, and is litigated frequently, see, e.g., Peeler v. Longview Indep. School Dist., 485 F. Supp. 117 (E.D. Tex. 1979); Crowe v. Lucas, 479 F. Supp. 1258 (N.D. Miss. 1979). See generally Berger, Court Awarded Attorneys' Fees: What is "Reasonable'?, 126 U. PA. L. REv. 281, 281-94 (1977). Leaving the decision whether to award fees to the trial judge's discretion is therefore unlikely to decrease the amount of fees litigation. Finally, mootness is an infrequent issue in section 1988 claims. So long as the rules themselves do not provide incentives for mooting or manipulating cases, establishing rules of decision concerning fees awards in moot cases will not overly burden the courts with fees litigation.

ss 446 U.S. 754 (1980).

st Id. at 757 .

ss Some mooted cases would satisfy this test. E.g., Bagby v. Beal, 606 F.2d 411 (3d Cir. 1979) (plaintiff granted injunctive relief at trial on the merits before case mooted).

se See supra notes 37-38 and accompanying text. Congress sanctioned fees awards in 
plaintiff must demonstrate that he has obtained some of the relief he sought. The Court in that case found that the Seventh Circuit had awarded fees improperly when the plaintiffs' principal accomplishment had been the reversal of directed verdicts for the defendants; after that reversal, the plaintiffs were in no better position than when they filed their complaint. 57 The plaintiff in a moot suit is likewise no better off unless he has obtained some of the relief sought. Hanrahan therefore limits fees awards to those situations where the plaintiff has gained substantive relief before the suit was mooted.

Some courts further limit the Hanrahan principle by requiring that the outcome have some "public benefit." Aps Aparently these courts assume that because section 1988 was enacted to fill the gaps created by Alyeska, ${ }^{58}$ it extends only to those cases that would have qualified for fees under the private attorney general theory Alyeska rejected. Arguably, only suits achieving direct public benefit further Congress's intent to promote public interest litigation. ${ }^{60}$

There is nothing in the legislative history to support the "public benefit" limitation, however. Congress intended fees awards to be made to prevailing plaintiffs as a matter of course, not only when the litigation would have qualified under the private attorney general theory. ${ }^{\text {BI }}$ Furthermore, the "public benefit" principle

four situations where there is no final adjudication of the civil rights claim: consent decrees, settlements, awards pendente lite, and judgments on pendent non-civil-rights claims. See supra notes $36-38,40$, and accompanying text. One could argue that a literal reading of Hanrahan is supported by these examples in that each requires formal judicial involvement. The examples are best harmonized with one another and with expressions of general purposes, however, when viewed as situations in which the fee claimant has obtained relief that has become irrevocable. See supra notes 47-51 and accompanying text. This explanation is supported by the fifth class of cases mentioned in the Reports, where the plaintiff has prevailed "without formally obtaining relief." See supra note 39 and accompanying text. Indeed, in one of the cases exemplifying that circumstance, the court awarded fees in connection with state law claims that it dismissed for lack of federal subject-matter jurisdiction. Kopet v. Esquire Realty Co., 523 F.2d 1005 (2d Cir. 1975). See also Housz RBporT, supra note 7, at 7-8. Furthermore, the pro forma attention courts generally give to settlements and consent decrees can hardly be viewed as equivalent to a determination of entitlement to relief. $C$ f. infra notes $64-68$ and accompanying text.

${ }^{67}$ Hanrahan v. Hampton, 446 U.S. 754, 758-59 (1980).

" See, e.g., Meriwether v. Sherwood, 514 F. Supp. 433, 438 (S.D.N.Y. 1981), rev'd on other grounds sub nom. Russo v. New York, 672 F.2d 1014 (2d Cir. 1982); Pernas v. Parkview Towers Management Corp., 502 F. Supp. 1099, 1106 (D.N.J. 1980).

see supra notes 17-24 and accompanying text.

co Neither of the cases cited supra note 58 explains why the public benefit conferred by the suit is relevant to entitlement to a fees award. Analogy to pre-Alyeska cases seems the only plausible explanation.

ax See Columbia Note, supra note 3, at 367; supra note 24. 
amounts to judicial legislation. Alyeska held that it is for Congress, not the courts, to decide which cases are to be encouraged through fees awards. ${ }^{62}$ Congress decided the civil rights laws should have this preferred status. "In short, it appears that Congress intended that fees be recoverable in all suits brought under the statutes listed in section 1988," from every such suit, but because the public benefits from private civil rights enforcement suits in general. Therefore, judicial conceptions of the public's gain from a particular suit must be rejected as criteria for determining when a plaintiff has prevailed.

Although substantive relief is necessary before fees can be awarded, it is not sufficient; that it exists does not ensure that it was obtained through the lawsuit and for a civil rights violation. These problems were faced in a slightly different context by the First Circuit in Nadeau $v$. Helgemoe, ${ }^{64}$ which ended in a consent decree. ${ }^{65}$ The congressional reports support fee awards in these circumstances, ${ }^{68}$ but the court was concerned with two problems: first, the parties might have reached the same agreement even had there been no lawsuit, and second, the consent decree might not have remedied an actual civil rights violation. ${ }^{62}$ The court remanded for a determination whether the suit and consent decree resulted in civil rights relief. .8 $^{\text {s }}$

To guide this determination, Nadeau established a two-part test that is frequently used by other courts as the standard for "prevailing." The first part of the test is factual: was the suit or the filing of the suit a material factor in gaining relief?70 An affirm-

${ }^{62}$ Alyeska Pipeline Serv. Co. v. Wilderness Soc'y, 421 U.S. 240, 260-64 (1975); see Columbia Note, supra note 3 , at 368 .

bs Comment, supra note 3 , at 343.

of 581 F.2d 275 (1st Cir. 1978).

os Id. at 279 .

So Supra note 38 and accompanying text.

67 581 F.2d at $280-81$.

68 Id. at 279-81.

62 E.g., Robinson v. Kimbrough, 652 F.2d 458, 465-66 (5th Cir. 1981); COYOTE v. Roberts, 502 F. Supp. 1342, 1349 (D.R.I. 1980); Massachusetts Fair Share v. O'Keefe, 476 F. Supp. 294, 296-98 (D. Mass. 1979).

Justice Rehnquist recently wrote favorably of Nadeau. As compared to a test focusing only on whether the plaintiff obtained relief, he found that "Nadeau more closely approaches the intent of Congress" by requiring a showing of the legal sufficiency of the civil rights claim. Long v. Bonnes, $102 \mathrm{~S}$. Ct. 1476, 1479 (1982) (Rehnquist, J., dissenting from denial of certiorari).

${ }^{20} 581$ F.2d at 281 (plaintiffs entitled to some fees if their "suit and their attorney's efforts were a necessary and important factor in achieving the improvements"). See also Morrison v. Ayoob, 627 F.2d 669, 671 (3d Cir. 1980) ("the plaintiff is a prevailing party if the action was a material factor in bringing about the defendant's action"), cert. denied, 449 
ative answer indicates that the relief came to the party as a litigant, not as a bystander. The second part is largely a matter of law: were the plaintiff's civil rights claims sufficient to establish that the relief obtained was legally required of the defendant? ${ }^{71}$ An affirmative answer indicates that the relief came to the party not just as a litigant, but as a civil rights litigant.

The combined requirements of Hanrahan and Nadeau are consistent not only with Congress's language but with its purposes: they encourage civil rights suits by allowing awards when a plaintiff has remedied a civil rights violation through a lawsuit. ${ }^{72}$ No suits Congress intended to encourage would be discouraged by the Hanrahan/Nadeau three-part test. A plaintiff would be denied fees only under three circumstances: where the case became moot without furnishing any relief, the outcome was the result of forces unrelated to the case, or the plaintiff was not litigating a civil rights claim. The first two are unlikely enough that potential plaintiffs will not be discouraged by the prospect of being denied fees. The third will not frustrate congressional purposes because only suits without a substantial civil rights component will be deterred.

The test has two other virtues. First, it is not easily manipulable by the plaintiff, who will be prevented from exacting fees if his suit is not responsible for the relief or if it did not state a civil rights claim. Second, the test can function without extensive inquiries into the merits of moot claims.

\section{Applying the Criteria for Awards in Moot Cases}

\section{A. Demonstrable Substantive Relief}

Satisfaction of the requirement that the plaintiff achieve substantive relief must be determined with reference to the relief

U.S. 1102 (1981). This view corresponds to the concept of the lawsuit as the "catalyst" for relief. See supra note 39. As stated in Nadeau, 581 F.2d at 280-81, "[t] the key issue is the provocative role of the plaintiff's lawsuit . . . . [N]o award is required if the . . . plaintiff's suit was completely superfluous in achieving the improvements . . . " The amorphous concepts of "material factor," "catalyst," "provocative role," and "necessary and important factor" are treated with greater specificity infra in part III-B.

7581 F.2d at 281.

72 Some courts have held that the plaintiff may recover fees if he meets these criteria, even if the judgment on the merits is for the defendant. Ross v. Horn, 598 F.2d 1312, 1322 (3d Cir. 1979), cert. denied, 448 U.S. 906 (1980); Meriwether v. Sherwood, 514 F. Supp. 433, 435-36 (S.D.N.Y. 1981), rev'd sub nom. Russo v. New York, 672 F.2d 1014 (2d Cir. 1982); cf. Mader v. Crowell, 506 F. Supp. 484, 487 (M.D. Tenn. 1981) (prevailing party may recover fees for costs incurred preparing issues on which it lost). But cf. Luria Bros. v. Allen, 672 F.2d 347, 357-58 (3d Cir. 1982) (plaintiff whose civil rights claim rejected, but who succeeds on pendent state law claim, not a prevailing party). 
prayed for. Pernas v. Parkview Towers Management Corp. ${ }^{73}$ is illustrative. This case was a civil rights action, filed in the United States District Court for New Jersey, challenging a state dispossession statute. ${ }^{74}$ The plaintiff resided in an apartment owned by the defendant, who had sued her in state court for summary dispossession. The dispossession suit was later dismissed when Pernas moved to another apartment owned by Parkview. The federal suit was then dismissed as moot because Pernas was not threatened by a dispossession action. ${ }^{75}$

The court conceded that Pernas "might be considered a prevailing party because a settlement resulted in [her] relocation to another subsidized apartment." founded, and fees were properly denied. ${ }^{77}$ The relief Pernas obtained stemmed from a separate suit and did not match any of the relief she requested in the civil rights action. ${ }^{78}$ Although the federal suit may have resulted in the speedy resolution of the state suit, that was not an articulated goal of the federal suit. Pernas thus fails the substantive relief requirement.

The issue of whether there has been relief is distinct from the issue of how it was accomplished. The court in Ward $v$. Arkansas State Police ${ }^{79}$ ignored this distinction, properly denying fees but for the wrong reasons. Ward sued the state police in 1977 for racial discrimination in hiring and advancement practices. Several months later, a consent decree was entered in a separate suit brought by the federal government against the state police on the same grounds, seeking similar relief. Ward then passed a new entrance exam, devised pursuant to the consent decree, but joined the army before completing other aspects of the hiring process. ${ }^{80}$ The court dismissed Ward's case as moot because he had abandoned his attempt to be employed by Arkansas, and it denied his

7s 502 F. Supp. 1099 (D.N.J. 1980).

${ }^{24}$ N.J. REv. STAT. \& 2A:18-59 (1951).

78502 F. Supp. at 1102-03.

76 Id. at 1106 .

77 The court denied fees because the suit conferred no public benefit. Id. at 1106. But see supra notes 58-63 and accompanying text (rejecting public benefit theory for fees awards determinations).

78 Pernas had sought class certification, a declaratory judgment that the statute was unconstitutional, an injunction to allow her to stay in the apartment, and compensatory damages. $I d$. at 1101-03.

${ }^{30} 493$ F. Supp. 1315 (E.D. Ark. 1980), rev'd on other grounds, 653 F.2d 346 (8th Cir. 1981). Because this case was brought under Title VII of the Civil Rights Act of 1964, the fees issue arose under 42 U.S.C. $\$ 2000 \mathrm{e}-5(\mathrm{k})$, not under section 1988 . The same principles of decision apply under each provision, however. See supra note 24.

so 493 F. Supp. at $1316-20$. 
request for attorney's fees, holding that a plaintiff whose case is dismissed as moot cannot be a prevailing party. ${ }^{81}$ The court noted that the only definite relief Ward achieved was the opportunity to take the new exam, a result it considered "superfluous." Br But the opportunity to take an unbiased exam was neither superfluous nor insubstantial, given that Ward had failed the old exam twice ${ }^{\text {ss }}$ and that passing the exam was a necessary step toward the employment and back pay he sought. Ward benefited from the relief granted his class through the consent decree and thus achieved substantive relief after filing his suit.

\section{B. Material Factor in Obtaining Relief}

Although Ward obtained relief, fees were properly denied because his lawsuit was not a material factor in obtaining that relief. Ward benefited exclusively from the federal government's suit.84 In contrast, in other cases the lawsuit is manifestly the sole cause for the plaintiff's relief. ${ }^{85}$ For example, if a student sues to be able to play sports during his senior year of high school and a preliminary injunction is issued allowing him to do so, the student has obtained full relief as a direct result of the lawsuit, even though the suit is soon mooted by his graduation. ${ }^{86}$

Establishing causation is not always so straightforward. The

aI Id. at 1328. On appeal, the Eighth Circuit held that Ward's suit was not moot and remanded for trial. Ward v. Arkansas State Police, 653 F.2d 346 (8th Cir. 1981). It did not reach the fees issue, stating only that if Ward proved his discrimination claim, he would be entitled to attorney's fees. Id. at 350 .

2493 F. Supp. at 1324.

ss See id. at 1316.

- See supra note 70 and accompanying text. The reasoning of the Eighth Circuit in finding that Ward's case was not moot lends support to this argument. The court noted that because the federal government's case was not brought as a class action, the consent decree entered in that suit was not Ward's only avenue for relief. In fact, the disposition of the federal government's suit was not relevant to Ward's individual claims. $653 \mathrm{F.2d}$ at $\mathbf{3 5 0}$. Moreover, the court noted, Ward's abandonment of the hiring process might affect the amount of back pay he could recover, but it did not moot his claim. Id. The court's rigid separation of the two suits suggests that Ward's benefit from the government's suit is irrelevant to the question of fees in his own case, not because the relief was not substantive, but because it did not result from his lawsuit.

ss E.g., Williams v. Alioto, 625 F.2d 845 (9th Cir. 1980) (preliminary injunction issued against police investigatory procedures in murder investigation; fees awarded where case mooted before appeal), cert. denied, 450 U.S. 1012 (1981); Bagby v. Beal, 606 F.2d 411, 41415 (3d Cir. 1979) (trial court ordered hearing to determine whether plaintiff should be suspended; fees awarded where hearing held before appeal of order heard, mooting case).

se E.g., Doe v. Marshall, 622 F.2d 118 (5th Cir. 1980), cert. denied, 451 U.S. 993 (1981); Kimbrough v. Arkansas Activities Assoc., 574 F.2d 423 (8th Cir. 1978); Buckton v. NCAA, 436 F. Supp. 1258 (D. Mass. 1977). 
difficulties are illustrated by a series of cases involving legislative preemption. ${ }^{87}$ A plaintiff brings suit challenging the constitutionality of a statute, and the legislature moots the case by amending or repealing the statute. The courts have properly required that there be a causal link between the suit and the legislature's corrective action, ${ }^{88}$ but they have consistently placed the burden of proving causation on the plaintiff. ${ }^{88}$

For three reasons, a rule allocating to the plaintiff the burden of proving causation effectively results in a per se rule against fees awards in cases of voluntary compliance ${ }^{90}$ and non-court-ordered relief. ${ }^{.1}$ First, it is difficult to establish that litigation was the sole

${ }^{87}$ E.g., American Const. Party v. Munro, 650 F.2d 184 (9th Cir. 1981); Bly v. McLeod, 605 F.2d 134 (4th Cir. 1979); Criterion Club v. Board of Comm'rs, 594 F.2d 118 (5th Cir. 1979); International Soc'y for Krishna Consciousness, Inc. v. Andersen, 569 F.2d 1027 (8th Cir. 1978); COYOTE v. Roberts, 502 F. Supp. 1342 (D.R.I. 1980), supp. op. issued, 523 F. Supp. 352 (D.R.I. 1981); Cicero v. Olgiati, 473 F. Supp. 653 (S.D.N.Y. 1979).

ss E.g., Criterion Club v. Board of Comm'rs, 594 F.2d 118, 120 (5th Cir. 1979) (fees appropriate "if the result obtained was a consequence of the filing of this suit"); Cicero v. Olgiati, 473 F. Supp. 653, 654 (S.D.N.Y. 1979). See generally supra notes 70, 84-86, and accompanying text.

so E.g., American Const. Party v. Munro, 650 F.2d 184, 188 (9th Cir. 1981) (plaintiff must "establish some sort of clear, causal relationship between the litigation brought and the practical outcome realized") (emphasis in original); Cicero v. Olgiati, 473 F. Supp. 653, 655 (S.D.N.Y. 1979) (conceding that where legislative reform is sweeping, the burden "must be considered extremely heavy").

90 E.g., Robinson v. Kimbrough, 652 F.2d 458 (5th Cir. 1981) (plaintiffs sued to include more blacks and women on jury lists; defendants recompiled jury lists accordingly; fees should be awarded on remand if compliance resulted from the lawsuit); Morrison v. Ayoob, 627 F.2d 669, 671 (3d Cir. 1980) (fees awarded where challenged practice abandoned after suit filed but before trial, mooting case), cert. denied, 449 U.S. 1102 (1981); Oldham v. Ehrlich, 617 F.2d 163, 168 (8th Cir. 1980) (challenged regulation was amended before trial; fees awarded because it was "virtually certain [the old regulation] would have been held invalid"); Lackey v. Bowling, 476 F. Supp. 1111 (N.D. III. 1979) (plaintiffs challenged state's withholding of unemployment insurance benefits; fees awarded where state changed policy before trial, after federal government advised that state incorrectly interpreted federal law).

22 This result would be contrary to congressional intent: both committee reports endorsed awards in cases that end through settlement, consent decrees, and voluntary compliance. House REPORT, supra note 7, at 7-8; SENATE REPORT, supra note 4, at 5, reprinted in 1976 U.S. Code Cong. \& AD. News at 5912.

There are many circumstances in which the desired outcome is achieved, and the case mooted, without court-ordered relief. E.g., Ward v. Dearman, 626 F.2d 489 (5th Cir. 1980) (state election procedure challenged for noncompliance with Voting Rights Act; procedure not readopted); Marci v. City of New Haven, 503 F. Supp. 6 (D. Conn. 1980) (plaintiff dismissed from city employment; new mayor reinstated plaintiff before trial); Pernas v. Parkview Towers Management Corp., 502 F. Supp. 1099 (D.N.J. 1980) (defendant sued plaintiff for dispossession; plaintiff brought civil rights action challenging state dispossession law; dispossession suit settled, mooting civil rights suit); Flesch v. Eastern $\mathrm{Pa}$. Psychiatric Inst., 472 F. Supp. 798 (E.D. Pa. 1979) (plaintiff filed lawsuit and internal grievance to challenge dismissal; grievance arbitrator ordered her reinstated before lawsuit heard). See also the cases concerning legislative preemption cited supra in note 87. 
cause for relief when that relief was not ordered by a court.2 Second, because relief results from the voluntary actions of a party, the question of causation hinges on that party's motivation. A defendant therefore might avoid having to pay fees merely through averments that the litigation did not prompt the mooting acts.9 This tactic has been successful in the legislative preemption cases. ${ }^{24}$ Third, the motivating or causal factors often lie outside the control of the fee claimant, 98 who has no access to proof of causation.

A different allocation of the burdens of proof and persuasion would alleviate these problems. The plaintiff should have the burden of introducing evidence showing that the litigation was at least one cause for his relief, a burden that could be satisfied through inferences drawn from the chronology of events. ${ }^{.6}$ The defendant could then present evidence in rebuttal, and the conflicting evidence would be weighed." In weighing the evidence, the plaintiff's chronology-based inferences should be entitled to greater weight when other relevant evidence "is under defendant's control and not easily available to plaintiff." This reflects the conventional practice of allocating the burden of proof according to the parties' access to the evidence. ${ }^{89}$

Placing the burden of persuasion as to causation on the defendant advances the purposes of section 1988. Congress wanted people who use litigation to remedy civil rights violations to be certain

${ }^{22}$ Morrison v. Ayoob, 627 F.2d 669, 671 (3d Cir. 1980), cert. denied, 449 U.S. 1102 (1981).

os Id.

* Such denials were effective in American Const. Party v. Munro, 650 F.2d 184 (9th Cir. 1981), for example, despite one legislator's affidavit averring that the suit was discussed in committee before the bill was discharged and that the suit "was an important factor in leading the House to repeal the challenged former law," " $i d$. at 186.

"s Nadeau v. Helgemoe, 581 F.2d 275, 281 (1st Cir. 1978).

* Id.; see Commissioners Court v. United States, 683 F.2d 435, 442 (D.C. Cir. 1982).

"7 The supplemental opinion in COYOTE v. Roberts, 523 F. Supp. 352 (D.R.I. 1981), offers a similar discussion. The court there held that the plaintiff has the burden of going forward with evidence of causation and that inferences drawn from chronology may at times satisfy this initial burden. The defendant may then rebut the plaintiff's showing. COYOTE departs from the argument here, however, in placing the risk of nonpersuasion on the plaintiff. Id. at 356.

88 Nadeau v. Helgemoe, 581 F.2d 275, 281 (1st Cir. 1978); cf. Commissioners Court v. United States, 683 F.2d 435, 442 (D.C. Cir. 1982) ("Because this portion of the inquiry involves facts that are totally within the control of the [party seeking to avoid fees], the court must rely on whatever objective data are available.").

" E.g., United States v. New York, N.H. \& H.R.R., 355 U.S. 253, 256 n.5 (1957) ("The ordinary rule, based on considerations of fairness, does not place the burden upon a litigant of establishing facts peculiarly within the knowledge of his adversary."). 
that they will be reimbursed for their legal fees. ${ }^{100}$ In a case in which it is as likely as not that the litigation resulted in the relief, this congressional concern for certainty should decide the matter in favor of the fee claimant. The same concern for certainty explains why fees should not be denied automatically if the litigation was not the sole cause for relief: a plaintiff whose suit has contributed to obtaining relief should not be denied fees simply because other factors beyond his control (and therefore not predictable) also contributed to the outcome. ${ }^{101}$

\section{Cognizable Civil Rights Claim}

Requiring that the lawsuit be a material factor in obtaining relief does not prevent a plaintiff from casting his complaint in terms of a civil rights violation where none exists, solely to be eligible for section 1988 fees. Where there has been no civil rights violation, there is no statutory basis for a fees award. Yet mootness forecloses litigation on the merits of the claim to determine whether there has been such a violation.

Faced with this problem, the First Circuit in Nadeau held that fees should be denied when the plaintiff's claims "could be considered 'frivolous, unreasonable, or groundless." "102 This standard duplicates the threshold for federal subject-matter jurisdiction. ${ }^{103}$ Because almost any claim passes this jurisdictional test, ${ }^{104}$ the test does not impose any real limitation on fees awards and provides too little protection from strike suits. ${ }^{105}$

100 See supra notes $48-49$ and accompanying text.

${ }_{101}$ See, e.g., Morrison v. Ayoob, 627 F.2d 669, 671 (3d Cir. 1980), cert. denied, 449 U.S. 1102 (1981); Nadeau v. Helgemoe, 581 F.2d 275, 281 (1st Cir. 1978); Meriwether v. Sherwood, 514 F. Supp. 433, 435 (S.D.N.Y. 1981), rev'd on other grounds sub nom. Russo v. New York, 672 F.2d 1014 (2d Cir. 1982); Lackey v. Bowling, 476 F. Supp. 1111, 1115 (N.D. Ill. 1979).

103 Nadeau v. Helgemoe, 581 F.2d 275, 281 (1st Cir. 1978) (quoting Christiansburg Garment Co. v. EEOC, 434 U.S. 412, 422 (1978)). Accord, COYOTE v. Roberts, 502 F. Supp. 1342, 1350 (D.R.I. 1980) ("[T]he fact that the court might have ultimately rejected all or part of the plaintiff's claim does not bar a fee award so long as the claim has at least colorable merit when analyzed in light of established constitutional theory.").

${ }^{10 s}$ See Hagans v. Lavine, 415 U.S. 528, 536-43 (1974).

104 See id. at 564 (Rehnquist, J., dissenting) ("Under [the Court's] rationale it appears sufficient for jurisdiction that a plaintiff is able to plead his claim with a straight face.").

${ }^{105}$ At the time Nadeau was decided, it is possible that its test might have prevented fees awards in a few cases: the combination of the now-abandoned amount-in-controversy requirement for federal-question jurisdiction under 28 U.S.C. \& 1331 (1976) (current version at 28 U.S.C.A. § 1331 (West Supp. 1982)) and the unclear reach of 42 U.S.C. § 1983 (1976) before the decision in Maine v. Thiboutot, 448 U.S. 1 (1980), meant that many civil rights claims had to be brought under the more limited jurisdiction of 28 U.S.C. $\S 1343$ (1976). 
Some courts resolve the problem through ad hoc predictions of the plaintiff's chance for success on the merits. ${ }^{108}$ This approach is legitimate only if the information before the court shows that the plaintiff's claim entirely lacks factual support. ${ }^{102}$ As a general approach, it suffers from the opposite of the problem raised by the First Circuit's test: it would deny too many fees awards. An ad hoc predictive approach is tantamount to a direct test of the merits of the civil rights claim and is subject to the same manipulation as a per se rule against fees awards in moot cases: ${ }^{308}$ so long as there is no dispositive precedent in the plaintiff's favor, the defendant could acquiesce, moot the case, and avoid paying fees. Yet the plaintiff may well have had a meritorious civil rights claim-a claim that, had there been the trial that mootness prevents, he would have proved. ${ }^{109}$ Denying fees in such circumstances would frustrate the purposes of section 1988.

A reasonable middle course is to base the test on Federal Rule of Civil Procedure 12(b)(6)..$^{110}$ Fees would be denied only if there were no legal merit to the civil rights claim. The basic requirements of a plausible civil rights claim are sufficiently well known that the 12(b)(6) test would not generate uncertainty as to when fees might be awarded. Anyone considering filing suit has to frame

106 In Cicero v. Olgiati, 473 F. Supp. 653 (S.D.N.Y. 1979), for example, New York prisoners alleged that the state's parole standards and procedures were so vague that they violated the inmates' due process rights. The parole law, was amended before the case was tried, and both sides agreed the case was moot. Denying fees, the court stated that "there is a substantial question as to whether the complaint here can now be considered to state a valid claim," id. at 665 , because the Supreme Court had found that due process rights concerning parole are limited.

Similarly, in Bly v. McLeod, 605 F.2d 134 (4th Cir. 1979), college professors challenged a South Carolina law that prevented them from voting by absentee ballot. A temporary restraining order allowed them to vote in absentia in the election in question, and the legislature then amended the law, mooting the case. Id. at 136. The Fourth Circuit reversed a fees award because "[n]o adjudication of invalidity of the statute was made." Id. at 137. But then, inexplicably, the court said that "[b]ecause the claim was without merit, the factual/ legal condition sought to be changed by litigation did not deserve the suit." Id. at 139.

107 Such an option is necessary to avoid fees awards in cases in which the defendant's .preliminary proofs are overwhelming, making it nonsensical for the court to assume that the facts as pleaded by the plaintiff are true. Cf. infra note 112 and accompanying text. This factual evaluation supplements the rule $12(b)(6)$ test outlined infra in the text and notes following note 110 . Both prevent fees awards where it is clear the plaintiff could not possibly have won had the case gone to trial.

100 See supra notes 50-51 and accompanying text.

100 A direct test of the merits is improper because "the merits of the action are not controlling" when litigating section 1988 fees in a moot case. Lackey v. Bowling, $476 \mathrm{~F}$. Supp. 1111, 1113 (N.D. Ill. 1979).

110 FED. R. Crv. P. 12(b)(6) (defense of "failure to state a claim upon which relief can be granted"). 
a complaint that will withstand a $12(b)(6)$ motion just to be able to stay in court; using the same test in the fees context would therefore have no material impact on the number of claims brought. The test would advance the congressional purpose of rewarding plaintiffs who have remedied civil rights violations through litigation while denying fees in suits with no legally cognizable civil rights claim.

One court has rejected the rule 12(b)(6) test because it would entail deciding questions no longer at issue. ${ }^{111}$ This conclusion misconceives the nature of the inquiry. For purposes of rule 12(b)(6), the facts as pleaded by the plaintiff are assumed to be true, and the complaint is dismissed only if, as a matter of law, the plaintiff could not possibly win. ${ }^{112}$ It is true that a $12(b)(6)$ ruling goes to the merits of the claim and that, technically, testing the merits of a moot claim is improper. But any decision about a fees award is an implicit statement about the merits of the claim. Moreover, it would surely violate Congress's intent if fees were awarded to a plaintiff who would not have obtained relief and therefore could not have received fees if the suit had been litigated to a final judgment. Fees cannot be awarded when it is clear, even without a trial, that the plaintiff would have lost.

\section{Conclusion}

The Civil Rights Attorney's Fees Awards Act of 1976 was enacted to promote civil rights enforcement. Intending that private litigation be the principal method of civil rights enforcement, Congress authorized awards for attorney's fees to the "prevailing party" in civil rights suits, thereby removing cost as a barrier to litigation. A final judgment is not required by section 1988, but to be eligible for a fees award it is necessary that a plaintiff obtain relief for a civil rights violation through a lawsuit. A blanket rule denying fees awards in all moot cases would be anomalous and would frustrate the purposes of the Act. A litigant would be discouraged from bringing suit for fear of having to pay his own legal costs in the event of mootness, despite the fact that he might have remedied a civil rights violation through his suit. It is consistent with both Congress's language and its purposes to award attorney's fees in moot cases when the plaintiff has achieved some of the re-

111 COYOTE v. Roberts, 502 F. Supp. 1342, 1349-50 (D.R.I. 1980).

112 See Kugler v. Helfant, 421 U.S. 117, 125 \& n.5 (1975); Conley v. Gibson, 355 U.S. 41, 45-46 (1957). See also supra note 107 and accompanying text. 
lief prayed for in his complaint, when the litigation was a cause for the relief, and when the suit concerned a legally cognizable civil rights claim. ${ }^{118}$

Matthew D. Slater

11 Although this comment has addressed only mootness and section 1988, its conclusions are relevant any time a suit ends without formal adjudication, see supra notes 37-40, and a fees claim is brought under a civil rights attorney's fees awards statute with a "prevailing party" standard, see supra note 14.

The analysis might also be relevant to litigation under the Equal Access to Justice Act, Pub. L. No. 96-481, \$8 208-204, 94 Stat. 2321, 2325-29 (1980) (codified in relevant part at 5 U.S.C.A. \& 504; 28 U.S.C.A. \& 2412 (West Supps. 1982)), in that it, too, authorizes fees awards to the "prevailing party." See supra note 2. Moreover, the legislative history states that "prevailing" does not require a full judgment on the merits and that civil rights attorney's fees case law applies to fees claims brought under the Equal Access to Justice Act. See H.R. RzP. No. 1418, 96th Cong., 2d Sess. 11-12 (1980), reprinted in 1980 U.S. Cods Cong. \& AD. News 4984, 4990-91; H.R. Conf. Rep. No. 1434, 96th Cong., 2d Sess. 21-22 (1980), reprinted in 1980 U.S. CoDs Cong. \& AD. NEws 5003, 5010-11. The Equal Access to Justice Act, however, denies fees if "the position of the United States was substantially justified." 28 U.S.C.A. \& 2412(d)(1)(A) (West Supp. 1982). See generally supra note 2. Thus, for example, if the plaintiff obtains relief as a result of legislative action, he may have prevailed but still not be entitled to fees. The mooting event suggests that the government's original position was justified: legislation was required to remedy the problem. 